\title{
Brugervenlig geologi på nettet - kort over vardifulde geologiske områder
}

Af Lise Holm, By-og Landskabsstyrelsen

Som led i kommuneplanlægningen bliver en del af kommunernes nye opgaver at sikre bevaringsværdige geologiske interesseområder. Det har resulteret i projektet om et landsdækkende kort over værdifulde geologiske områder. Region Midtjylland ligger allerede klar på nettet.

Alle, der interesserer sig for geologi, kan få stor glæde af hjemmesiden. Her får brugeren nemlig på hurtig og overskuelig vis indsigt i de værdifulde geologiske områder, og hvad man faktisk kan se på lokaliteten. Der er desuden en kort beskrivelse af lokalitetens værdi samt et foto af området og et kort med beliggenheden. På næste side er udvalgt et eksempel på en lokalitet - Bølling Sø. Der er indtil videre omkring 130 lokaliteter, på hjemmesiden, der er opført i alfabetisk rækkefølge, så man nemt kan

\section{Om kortet}

I forbindelse med strukturreformen i 2007 fik kommunerne nye planlægningsopgaver. Af Planlovens § 11a, stk.1, nr. 16 og “Oversigt over statslige interesser i kommuneplanlægningen 2009”, Kapitel 3,16 fremgår det, at også sikring af geologiske bevaringsinteresser som led i kommuneplanlægningen er en del af kommunernes nye opgaver. By- og Landskabsstyrelsen er i samarbejde med De Nationale Geologiske Undersøgelser for Danmark og Grønland (GEUS) ved at udarbejde et landsdækkende kort over værdifulde geologiske områder. Dette kort skal anvendes i den kommunale planlægning, og kommunerne skal formulere retningslinjer til sikringen af værdierne. Endvidere vil kortet være relevant for regionernes råstofplanlægning. Kortet er tilgængeligt online på Miljøportalen som et interaktivt temakort, og GIS-informationen kan downloades herfra.



Region Midtjylland ligger klar til brug på hjemmesiden. (Print fra Vœrdifulde geologiske områder i Region Midtjylland)

komme til hen til lokaliteten, hvis man kender den på forhånd - man kan også klikke direkte på kortet for at udvælge et område, man ønsker at se på.

Hvordan kortet er blevet til, kan man læse på hjemmesiden.

\section{Hvordan kortet skal anvendes}

Til hvert område er der knyttet en hjemmeside med en kortfattet geologisk beskrivelse af lokaliteten sammen med en angivelse af den geologiske værdi, som lokaliteten har for forskning, undervisning og almen geologisk interesse. Endvidere er der under Naturforvaltning angivet de overordnede retningslinjer, som har til formål at sikre og synliggøre de geologiske værdier. De mere konkrete retningslinjer for et område forventes den pågældende kommune at formulere.

Under Yderligere information er der et link til temakortet på Miljøportalen, hvor området er angivet. En Ordliste med forklaring på geologiske fagtermer er også tilknyttet. (Denne er dog pt. under udbygning). Nederst på siden er det angivet, hvorvidt et område er nationalt eller amtsligt geologiske interesseområde, nationalt kystlandskab eller et GeoSite. Her er der via indlagte links tilknyttet mere fyldige tilhørende beskrivelser.

\section{Hjemmesiderne}

De mange geologiske områder på hjemmesiderne er opdelt regionsvist. For at øge overblikket er Region Syddanmark opdelt i en Sydjyllandsdel og en Fynsdel. Tilsvarende er Region Hovedstaden opdelt i en Sjællandsdel og en Bornholmsdel. Således at der i alt er 7 regionsindgange. På disse regioners forsider linkes der til de enkelte områders individuelle sider. Da der kan være mere end 50 områder per region, vises for overskuelighedens skyld kun 50 ad gangen. Nederst på siden kan de næste 50 links findes ved at trykke på "næste”.

På de enkelte områders hjemmeside er der som nævnt et direkte link til temakortet.

\section{Søgefunktion}

Derudover findes en Søgefunktion. På hjemmesiderne er det via et link i højre side muligt at søge på alle ord, der er nævnt

Bliv klogere på geologi:

http://www.blst.dk/Landskab/GeologiskeInteresser/ 
på selve siderne, $\mathrm{fx}$ geologiske termer og kommunenavne. For at gøre en søgning om geologi mere komplet, er der på nogle af siderne tilføjet ekstra geologiske termer, som er karakteristiske for det pågældende område, men hvor ordet ikke indgår direkte i geologiteksten. Denne søgning er målrettet de geologiske sider og må ikke forveksles med den generelle søgning i øverste højre hjørne på hele By- og Landskabsstyrelsens hjemmeside. (OBS: Søgeordene om geologi er pt. under udbygning og er derfor endnu ikke fuldstcendige).

\section{Temakortet}

Temakortet er et Danmarkskort med et GIS tema-lag der viser den geografiske afgrænsning af områderne. Via temakortet kan der zoomes ind til individuelle områder, til kommuner og lignende. GIS-informationen kan dowloades, og der findes links herfra til yderligere information.

\section{Kontakt:}

Eventuelle spørgsmål og kommentarer bedes rettet til Lise Holm, By- og Landskabsstyrelsen: e-mailadresselho@blst.dk Tlf. 72544838.

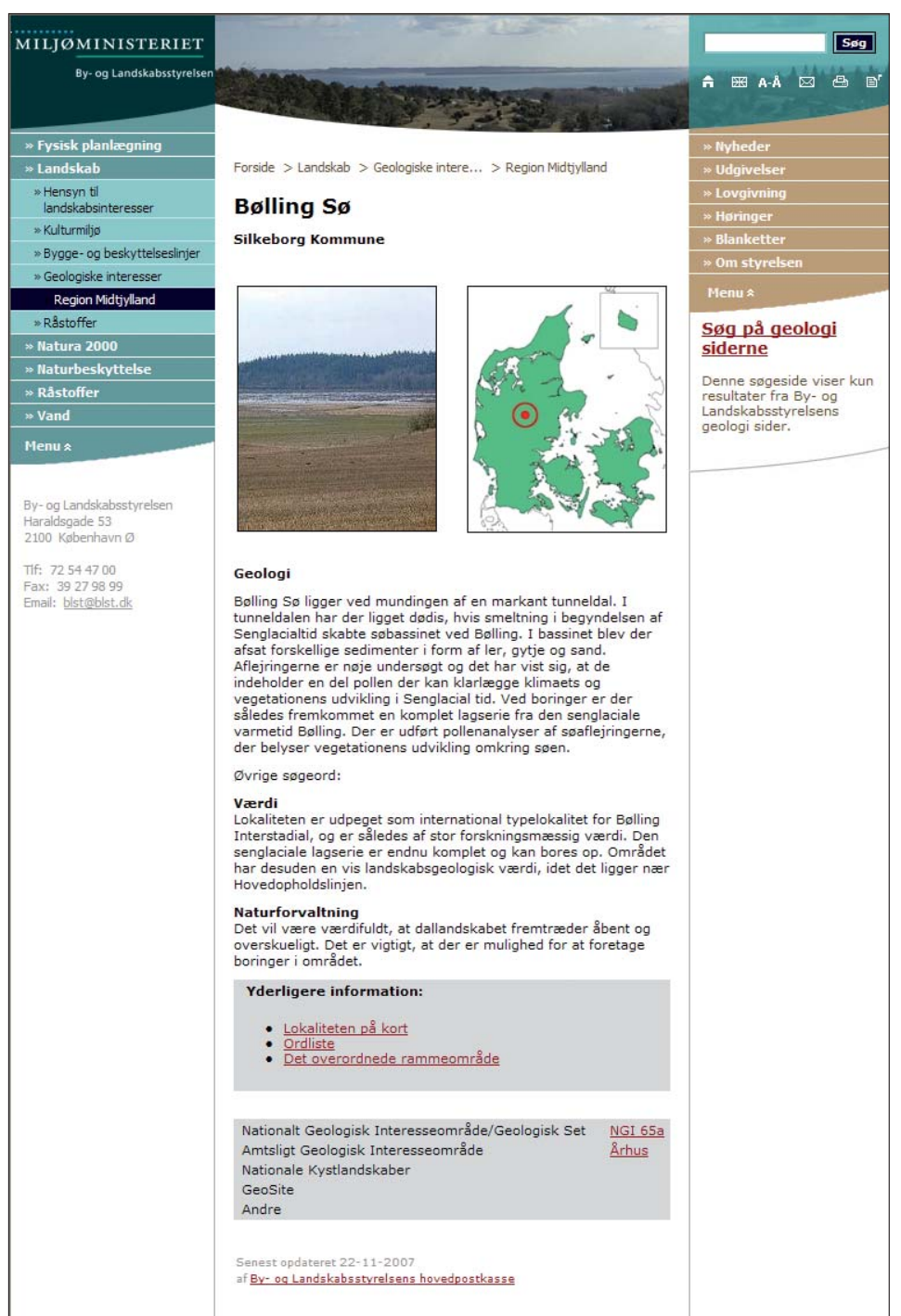

\section{Kort nyt}

\section{Fem danske nationalparker}

I løbet af de kommende to-tre år får Danmark fem nationalparker: Thy, Skjern Å, Vadehavet, Mols Bjerge og Kongernes Nordsjælland.

Thy nationalpark er allerede afgrænset og udpeget. Den omfatter 24.000 ha klitter, plantager og søer i det vestlige Thy fra Hanstholm i nord til Agger Tanges sydspids. Den ventes indviet til august.

Den endelige geografiske afgrænsning er politisk ikke faldet helt på plads endnu for et par af de sidste fire nationalparkers vedkommende. De politiske partier på Christiansborg er dog blevet enige om at afsætte 6-7 mio. kr. til etableringen af hvert projekt.
Det er meningen, at der skal nedsættes en bestyrelse for hver nationalpark og laves konkrete planer for, hvordan områderne kan udvikle sig gennem fx naturgenopretningsprojekter og faciliteter, der kan tiltrække turister og besøgende.

\section{$J P / S L J$}

Det reneste vand ligger under Aalborg Vejgaard Vandværk, der er Aalborg kommunes største private vandværk, har i en prøveboring midt i byen fundet vand, der er fuldstændigt fri for pesticider og nitrat - eller i det mindste med så ringe indhold, at det ikke kan måles. Nyheden er også særligt interessant, fordi flere boringer i nærheden har haft store pesticidværdier. Mens mange vandværker i selve Aalborg by således har måttet lukke, er Vejgaard Vandværks overlevelse sikret et stykke ud i fremtiden.

$/ E K$

\section{Jordskælv i Grækenland}

D. 14. februar rystede et jordskælv, der blev målt til 7,3 på Richterskalaen, det sydlige Grækenland.

Skælvet kunne mærkes kraftigst i Peloponnes-regionen tæt på Athen. Indbyggerne i området løb ud på gaden, da de mærkede skælvet. Ingen tilskadekomne eller større ødelæggelser er indløbet fra området.

Reuters/SLJ 